Agricultural Journal 14 (5): 79-93, 2019

ISSN: 1816-9155

(C) Medwell Journals, 2019

\title{
Review on the Epidemiology and Economic Impact of Foot and Mouth Disease in Ethiopia
}

\author{
Juhar Tesfaye \\ School of Veterinary Medicine, Wollo University, Dessie, Ethiopia
}

\begin{abstract}
Absract: Foot-and-Mouth Disease (FMD) is the most contagious, acute and economically important transboundary animal disease affecting cloven hoofed wild and domestic animals. It is caused by a virus that belongs to the genus aphthovirus of the family picornaviridae. There are seven recognized serotypes of FMD (O, A, C, Asia1, SAT1, SAT2 and SAT3) which differ in distribution across the world. It becomes endemic in Ethiopia and leads a great economic loss in the livestock's sector. Therefore, the objective of this study is to review the epidemiology and economic impact of FMD in Ethiopia. The seroprevalence, temporal, serotype and regional distribution, topotypes present, the direct and indirect economic impacts of FMD in Ethiopia are reviewed in this seminar paper. Foot and mouth disease outbreaks are occurred in Ethiopia every year and reported from all regions of the country. However, most of the outbreaks are reported from central, Southern and Southeastern part of Ethiopia associated with the movement of animals for trade, agro ecology, animal density and production system of the community. These outbreaks of FMD results in huge economic loss directly due to production losses and indirectly due to export restriction, control and prevention costs. Therefore, the epidemiology of the serotypes present should be studied in detail. This helps to develop a vaccine which is effective to all the serotypes present in Ethiopia. Control of animal's movement should be strengthened to limit spreading of serotypes.
\end{abstract}

Key words: Distribution, economic impact, ethiopia, foot and mouth disease, seroprevalence

\section{INTRODUCTION}

Foot-and-Mouth Disease (FMD) is the most contagious and acute Transboundary Animal Disease (TAD) affecting cloven hoofed wild and domestic animals (Sumption et al., 2007). FMD is caused by a virus that belongs to the genus aphthovirus of the family picornaviridae. There are seven recognized serotypes of FMD (O, A, C, Asia1, SAT1, SAT2 and SAT3) which differ in distribution worldwide. Serotypes A and O have the widest distribution. Infection or vaccination against one serotype does not provide protection against the other serotypes (Sumption et al., 2007). Out of the seven serotypes of FMD virus the existence of serotype O, A, C, SAT 1 and SAT 2 were reported in Ethiopia (Ayelet et al., 2009; Urge, 2017).

Livestock species including cattle, water buffalo (Bubalus bubalis), pigs, sheep and goats are susceptible to infection and can spread the disease (Sumption et al., 2007). FMD is endemic in most of sub-Saharan African countries. One study indicated that the occurrence of foot and mouth disease outbreak has been serious challenge every year in Ethiopia (Gelaye et al., 2009).

Foot and mouth disease viruses may occur in all secretions and excretions of acutely infected animals including expired air and can be transmitted by contact in two ways. Direct contact transmission between infected and susceptible individuals which is likely to account for the majority of infections and occasional transmission between carrier buffalo and susceptible individuals. It is widely accepted that the most common mode of FMD transmission is through physical contact between infected and susceptible animals, often as a result of movement of infected animals (Pharo and Cobb, 2011).

The predominant entrance of virus is most commonly through the upper respiratory tract by inspiration of infected aerosols but infection may also occur through a skin injury (Lyytikainen et al., 2011). After inhalation, the virus can affect the pharynx and primary multiplication of the virus in the mucous membrane is transported by lymphatic and blood circulation to the sites of secondary multiplication (Lefebvre et al., 2010). The severity of clinical signs of the disease varies with the strain of the virus, the exposure dose, the age and breed of the animal, the host species and its, degree of immunity. The signs can range from a mild or in apparent in sheep and goats to a severe disease occurring in cattle and pigs (DACA., 2004).

The accurate diagnosis of infection with FMDV is of prime most importance for both control and eradication campaigns in FMD endemic areas (Longjam et al., 2011). The disease is diagnosed based on clinical signs, however, the clinical signs can be confused with other diseases and thus, laboratory based diagnosis is necessary (Jamal and Belsham, 2013). For laboratory diagnosis, the sample of choice is tissue epithelium or vesicular fluid. Serum 
samples are also used for FMD diagnosis based on spiking of antibody against a particular serotype (Musser, 2004). Diagnosis of FMD in the laboratory is conducted by virus isolation, demonstration of the FMD viral antigens or nucleic acid in a sample tissue or fluid. Detection of virus specific antibodies can also be used. Additionally, antibodies to viral nonstructural protein can be used as indicators of infection irrespective of vaccination status (Grubman and Baxt, 2004).

Foot and mouth disease preventive measures include: control of national borders, prohibition of import of animals and livestock products from endemic countries in accordance with the OIE standards, emergency measures in the event of outbreaks through: stamping-out, followed by cleaning and disinfection to reduce the risk of re-infection, strict movement controls, extending to movement on and off farms of livestock products. And also possible emergency vaccination is important (Ding et al., 2013).

Foot and mouth disease is endemic and economically highly important disease in Ethiopia. Outbreaks were geographically widespread affecting all major regional states in the country and were more frequent in the central, Southern and Southeastern parts of the country (Ayelet et al., 2009).The high incidence in central Ethiopia could be associated with trade related animal movements. In Ethiopia, prices are higher in urban centers, the largest of which is Addis Ababa that is found in the center of the country and livestock usually move toward the center from other parts of the country. The Southern and Southeastern parts of the country are the main areas for cattle pastoralism and are also the main source of export animals. The higher incidence in these areas could be due to intensive animal movement both as a normal routine of the pastoral husbandry system and for the purpose of trade (Jemberu et al., 2016a).

In Ethiopia different researchers detected five of the seven FMDV serotypes (O, A, C, SAT1 and SAT2) (Gelaye et al., 2009; Urge and Gizaw, 2018; Menda et al., 2014). Geographically, the outbreaks were widely distributed. Most of the strains were distributed within central Ethiopia including the Addis Ababa administrative region; the rest were in Ahmara and Tigray in the North, Dire Dawa in the Northeast, Beneshangul-Gumuz bordering Sudan in the West and Southern Nations Nationalities and Peoples Region bordering Kenya and Sudan in the South. In Eastern Ethiopia, poor veterinary services and inaccessibility to the area could have resulted in the lack of samples submitted (Ayelet et al., 2009).

Foot and mouth disease causes the highest economic impact on the poorest countries like Ethiopia where the livelihood of most of the people depends directly on livestock. This impact can be divided into two components: direct impacts due to production losses and change in herd structure and indirect impacts due to FMD control costs, limited access to market and limited use of new production technologies (Rushton, 2009) FMD impacts in terms of visible production losses and vaccination in endemic countries can cause losses of >USD 1.5 billion per year (Knight-Jones and Rushton, 2013). In Ethiopia FMD is posing a major threat thereby causing substantial economic losses through morbidity and mortality (Abdela, 2017). According to Jemberu et al. (2016b) the total annual losses due to FMD estimated based on production losses, export losses and control costs to be greater than 1350 million Birr and the major cost is due to production losses. Therefore, the objective of this seminar is: to review the epidemiology and economic impact of foot and mouth disease in Ethiopia.

Overview on foot and mouth disease: Foot-and-Mouth Disease (FMD) is the most contagious and acute Transboundary Animal Disease (TAD) affecting cloven hoofed wild and domestic animals (Sumption et al., 2007). It is one of the most economically important animal diseases in the world (Knight-Jones and Rushton, 2013).

Etiology: FMD is caused by a virus that belongs to the genus aphthovirus of the family picornaviridae. The virus causing FMD was defined in 1963 by the Intemational Committee of Taxonomy of viruses as belonging to the genus aphthovirus, one of the genera of the family picornaviridae. The name picornaviridae is derived from the Latin word 'pico' (small) and 'ma' (RNA) which refers to the size and genome type while the genus name 'aphthovirus' refers to the vesicular lesions produced in cloven hoofed animals. FMD virus is a single-stranded, non-segmented, positive sense RNA virus of approximately $8.2 \mathrm{~kb}$ that belongs to the genus aphthovirus of the family picornaviridae. The virus is inactivated when exposed to $\mathrm{pH}$ below 6.5 or above 9 . However, the virus can survive $\mathrm{pH}$ of 4.6 in milk and milk products. The virus can be also easily inactivated by heat, UV radiation and gamma irradiation, chemicals and disinfectants (Murphy et al.,1999). The virus may persist for days or weeks in organic matter under moist and cold conditions. It can survive in frozen bone marrow, lymph nodes and also in cheese during its processing. The virus in milk and meat can be inactivated by heating at the temperature of $70^{\circ} \mathrm{C}$ for at least $30 \mathrm{~min}$ (Awan, 2009).

There are seven recognized serotypes of FMD (O, A, C, Asia1, SAT1, SAT 2 and SAT 3) which are distributed around the world. Serotypes A and O have the widest distribution, occurring in Africa, Asia and South America. Types SAT 1, SAT2 and SAT3 are restricted to Africa only and Asia1is restricted to Asia; the capacity to invade free areas is common to all types and periodically SATs are introduced into the Near East and Asia-into Western 
Agric. J., 14 (5): 79-93, 20190

and Eastern parts of Eurasia. Infection or vaccination against one serotype does not provide protection against the other serotypes(Sumption et al., 2007).

\section{Epidemiology of foot and mouth diseases}

Host range and geographic distribution: Livestock species including cattle, water buffalo (Bubalus bubalis), pigs, sheep and goats are susceptible to infection and can spread the disease. The disease is considerably less obvious or sub-clinical in breeds of cattle, sheep and goats indigenous to Africa and Asia where FMD is endemic and these animals are believed to have been the source of infection for countries previously considered disease-free (Sumption et al., 2007).

FMD is endemic in most sub-Saharan African countries. It has been effectively controlled in South Africa, Botswana, Namibia, Swaziland and Lesotho which manage to maintain FMD freedom without vaccination in large zones of their territories through control zones in which vaccination is routinely practiced and cordon fences prevent entry into free zones from the wildlife reservoir (Sumption et al., 2007). Studies indicated that the occurrence of foot and mouth disease outbreak has been serious challenge every year in Ethiopia (Ayelet et al., 2009). The national incidence of FMD outbreaks during 2007-2012 was 1.45 outbreaks per 5 district years. Outbreaks were geographically widespread affecting all major regional states in the country and were more frequent in the central, Southern and Southeastern parts of the country (Jemberu et al., 2016a).

Morbidity and mortality: Foot and mouth disease has high morbidity rate and low mortality rate. The type of breed, the production system, age group, absence of restriction of animal movement, animal density, use of communal pasture and watering points and season are among the major factors associated with the morbidity and mortality rate of the disease (Jemberu et al., 2016a). Exotic breeds appeared more susceptible to the FMD viruses endemic to Ethiopia. The morbidity rate of the disease was relatively lower in indigenous breed of cattle (8.5\%) than the other breeds (Negusssie et al., 2011). The putative risk factors such as age, agro ecology and production systems were statistically significantly associated with FMD seropositivity in cattle (Mesfine et al., 2019).

Transmission: FMD viruses may occur in all secretions and excretions of acutely infected animals including expired air and can be transmitted in two ways. Direct contact transmission between acutely infected and susceptible individuals which is likely to account for the majority of infections and occasional transmission between carrier animals and susceptible individuals. It is widely accepted that the most common mode of FMD transmission is through physical contact between infected and susceptible animals, often as a result of movement of infected animals (Pharo and Cobb, 2011). Generally, cattle and pig mainly get infection through inhalation and ingestion, respectively. Under specific climate conditions (particularly downwind), aerosolized FMDV produced by infected pigs can travel a significant distance infecting cattle and sheep from 20-300 and 10-100 km away, respectively (Savill et al., 2006).

Pathogenesis and clinical signs: Mainly the virus entrance is through respiratory system by inhalation even though entrance through skin is possible. After inhalation, the primary multiplication sites are pharynx and mucous membrane the virus then affects lymphatic glands and epithelial tissues in and around the mouth, feet and in the mammary glands through lymphatic system and blood circulation (Lefebvre et al., 2010). The virus appears in different body fluids such as milk, urine, respiratory secretions and semen before the appearance of clinical signs of FMD. The virus can also persist in oral cavity of infected animals for long periods after the acute infection (Alexandersen et al., 2003).

The severity of clinical signs of the disease varies with the strain of the virus, the exposure dose, the age and breed of the animal, the host species and its degree of immunity. The signs can range from a mild or in apparent in sheep and goats to a severe disease occurring in cattle and pigs (DACA., 2004).

The acute phase of disease lasts about 1 week and declines gradually coinciding with the emergence of a strong humeral response. In sheep and goats symptoms are frequently mild and may make the detection of the disease difficult (Chase-Topping et al., 2013). Lameness is usually the first indication of FMD in sheep and goats. An affected animal develops fever is reluctant to walk and may separate itself from the rest of the flock. Vesicles may develop in the interdigital cleft on the heal bulbs and on the coronary band but they usually rupture rapidly (Kitching and Hughes, 2002). In fatal cases, death is caused either by dehydration or by ventricular fibrillation during cardiac attacks or as a result of bacterial complication (Lefebvre et al., 2010).

FMD in Bovine characterized by fever (above $40^{\circ} \mathrm{C}$ ), excessive salivation, lameness, depression and decreased milk production which requires a differential diagnosis from other vesicular diseases (Longjam et al., 2011). The mucosa of the lips, dorsum of the tongue and the dental plate are most severely involved. Lesions are often observed initially as blanched areas which subsequently develop into vesicles. The vesicles rupture and then heal whilst coronary band lesions may give rise to growth arrest lines that grow down the side of the hoof (World Organization of Animal Health (OIE), 2012). 
Agric. J., 14 (5): 79-93, 20190

FMD in pigs primarily affects the feet. It is dominated by rather painful formation of vesicles in the epidermis of the feet (coronary band, interdigital clefts and bulbs) associated with severe lameness. Detachment of the hoof can be developed after secondary complication of the ruptured vesicle by microorganisms (Kitching and Hughes, 2002).

Diagnosis techniques of FMD: The accurate diagnosis of infection with FMDV is of prime most importance for both control and eradication campaigns in FMD endemic areas (Longjam et al., 2011). The disease can be diagnosed based on clinical signs including high temperature, excessive salivation and formation of vesicles on the oral mucosa, on the nose plus the inter-digital spaces and coronary bands on the feet. However, it is impossible to distinguish foot and mouth disease from the other vesicular diseases of the viral origin clinically. Vesicular stomatitis, vesicular exanthema and Swine vesicular disease required laboratory studies to differentiate them from foot and mouth disease (Jamal and Belsham, 2013).

For laboratory diagnosis, the sample of choice is tissue epithelium or vesicular fluid collected from an unruptured or recently ruptured vesicle, usually from the tongue, buccal mucosa or feet. When epithelial tissue is not available, for example in advanced or convalescent cases or where infection is suspected in the absence of clinical signs, samples of oropharyngeal fluid is collected by means of a probang cup (or in pigs by swabbing the throat) for diagnosis. Serum samples are also used for FMD diagnosis based on spiking of antibody against a particular serotype (Musser, 2004). Diagnosis of FMD in the laboratory is conducted by virus isolation, demonstration of the FMD viral antigens or nucleic acid in a sample tissue or fluid and detection of virus specific antibodies (Grubman and Baxt, 2004).

Virus isolation: The isolation and characterization of the virus is the "golden standard" for the diagnosis of viral diseases (Admassu et al., 2015). Virus isolation requires the presence of infectious virus which depends on sample quality. Up to 4 days may be required to demonstrate the presence of virus, especially when the levels of virus are low (Jamal and Belsham, 2013). Sensitive cell culture systems include primary bovine (calf) thyroid cells and primary pig, calf or lamb kidney cells. Established cell lines such as BHK-21 (baby hamster kidney) and IBRS-2 cells may also be used but are generally, less sensitive than primary cells for detecting low amounts of infectivity. The sensitivity of any cells used should be tested with standard preparations of FMDV (Sissay et al., 2017). Pig cell lines were not always suitable for isolation of FMDV coming from other species (Bouma et al., 2001). The BHK-21 cell line seems to be less species dependent. The cell cultures should be examined for Cytopathic Effect (CPE) for 48 h. If no CPE is detected, the cells should be frozen and thawed used to inoculate fresh cultures and examined for CPE for another $48 \mathrm{~h}$. In the case of OP fluids, pretreatment with an equal volume of chloro-fluoro-carbons may improve the rate of virus detection by releasing virus from immune complexes (Sissay et al., 2017).

Serological approaches: Serological tests are widely used to evaluate the level of antibodies produced when animals are exposed to FMDV or FMDV vaccines. Approaches used include Enzyme Linked Immunosorbent Assays (ELISAs) and Virus Neutralization Tests (VNTs), although, Complement Fixation Tests (CFT) are still used in a limited number of laboratories. Previous or current infections can be diagnosed by using antibodies to FMDV structural proteins and include: ELISAs [Solid-phase competition ELISA (SPCE), Liquid-phase blocking ELISA (LPBE)] and Virus Neutralization Tests (VNT) (gold standard test) which are serotype specific (Deb et al., 2013).

One particular application of these serological assays is to identify animals in a vaccinated herd that have been infected with FMDV. This, so called DIVA (differentiating infected from vaccinated animals) principle exploits differences in the antibody (humoral) responses generated in vaccinated animals compared to those animals naturally infected with FMDV (whether or not they have been vaccinated). High quality FMDV vaccines are purified to contain Structural Protein (SP), viral capsid components from which most of the viral Non-Structural Proteins (NSP) have been removed. In contrast during natural infection with FMDV, viral NSP are expressed that elicit a corresponding immune response that can be detected using diagnostic approaches (Ludi et al., 2017).

Nucleic acid recognition method: The PCR techniques are the most widely used nucleic acid based diagnostic technique for rapid identification of FMD virus (Xu et al., 2013). A specific reverse transcriptase polymerase chain reaction was developed and validated for the detection of the polymerase gene (3D) of FMD with a sensitivity equal to 1000 times higher than that of a single passage virus isolation (Longjam et al., 2011).

Real time PCR assays recommended by the World Organization for Animal Health (OIE) for detection of FMDV incorporate universal primers and fluorescent labeled probes that recognize conserved region within the 5' UTR or conserved gene regions within the RNA-dependent RNA polymerase gene (Reid et al., 2000). This is most sensitive and rapid method to detect the nucleic acid. The viral RNA can be consistently detected over a seven-log range, the lowest of which corresponded 
to as few as 10-100 RNA per volume tested. The test can be performed in $2 \mathrm{~h}$ or less on a portable instrument and sample can be held at ambient temperatures. Real time chemistry allows for the detection of PCR amplification during the early phases of the reaction and real time PCR monitors the progress of a PCR reaction in the real time. At the same time, a relatively small amount of PCR products (DNA or cDNA) can be quantified (Shaw et al., 2007).

Prevention and control: Being a viral disease FMD has no treatment, so, preventive measures in the absence of disease should be implemented as follows: control of national borders to prevent significant movement of animals and livestock products, prohibition of imports of animals and livestock products from endemic countries, emergency measures in the event of outbreaks through: rapid slaughter of infected animals and in contact animals followed by cleaning and disinfection to reduce the risk of re-infection, strict movement controls, extending to movement on and off farms of livestock products. And also possible emergency vaccination is important (Ding et al., 2013).

In Ethiopia context the control of FMD is practiced by involvement of quarantine, isolation of infected animals, vaccination programs, proper disposal of infected carcass and other methods which are feasible to Ethiopian economy (Admassu et al., 2015). Two factors could explain the upsurge of outbreaks of FMD in some endemic areas like Ethiopia. One factor is the low level of immunity caused by inadequate vaccination strategies (quality, coverage and timing). The other is uncontrolled animal movement and products. Animal diseases such as FMD can only be successfully controlled if there is a strong regional focus and integrated regional strategies to improve biosecurity and regulatory oversight of the movement of animals between and within countries (Ayelet et al., 2012).

\section{RESULTS AND DISCUSSION}

\section{Status of FMD in Ethiopia}

\section{Outbreak and seroprevalence distribution of FMD}

Spatial distribution: In Ethiopia foot and mouth disease is endemic and economically important disease. The records of the Ministry of Agriculture and Rural Development from 2002-2006 indicate that FMD outbreaks occurred each year in Ethiopia during this period with the highest number in 2004, when 134 outbreaks were reported (MARD., 2006). The highest rates were from the North Shoa zones of both the Oromia and Amhara regions (Fig. 1) but no reports were brought from Gambella and Benishangul (Ayelet et al., 2012). Latter on the national incidence of FMD outbreaks during 2007-2012 was 1.45 outbreaks per 5 district years. Outbreaks were geographically widespread affecting all major regional states in the country and were more frequent in the central, Southern and Southeastern parts of the country. FMD has been reported from all major regional states in Ethiopia. The highest incidence of district level FMD outbreak was seen in the Addis Ababa city administration (4/5 district years) followed by Gambella regional state (3/5 district years). Mapping the disease by the eight geographical zones showed that the FMD outbreak incidence was above the national average in Southeastern (2.67/5 district years), central (2.28/5 district years) and Southern (1.88/5 district years) parts of the country (Jemberu et al., 2016a).

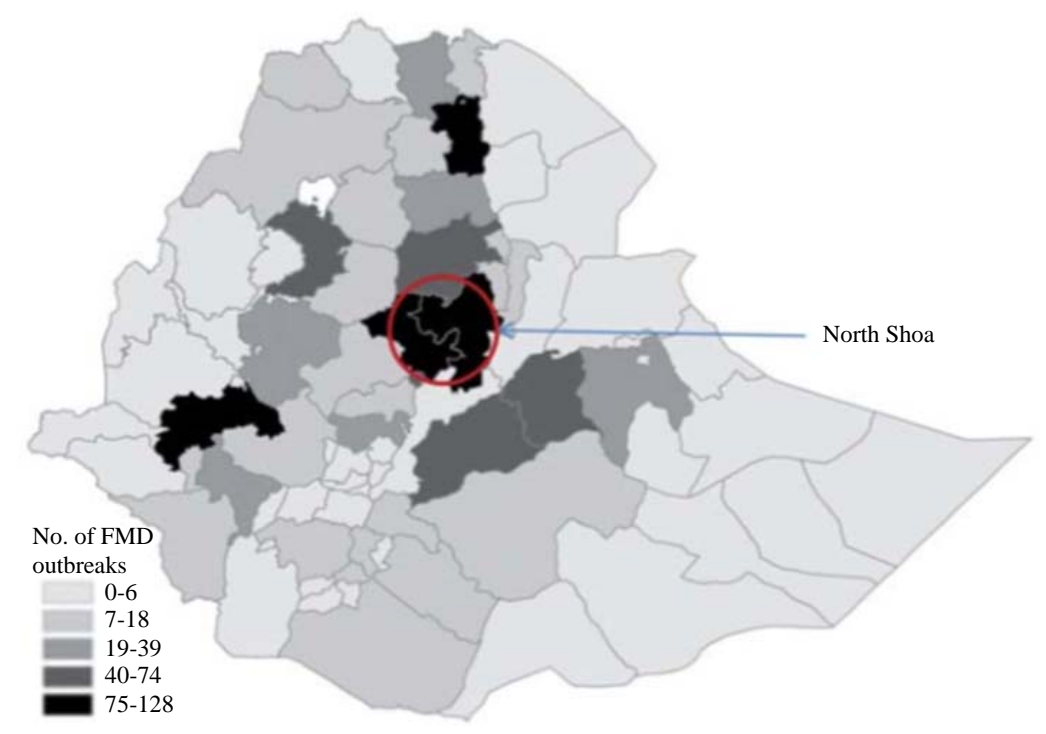

Fig. 1: Number of outbreaks occurred in Ethiopia during 2002 up to 2006 (Ayelet et al., 2009) 
FMD outbreaks were more common in the central, Southern and Southeastern parts of the country (Ayelet et al., 2009; Jemberu et al., 2016a). The high incidence in central Ethiopia could be associated with trade animal movements. In Ethiopia, prices are higher in urban centers, the largest of which is Addis Ababa that is found in the center of the country and livestock usually move toward the center from other parts of the country. The Southern and Southeastern parts of the country are the main areas for cattle pastoral's and are also the main source of export animals. The higher incidence in these areas could be due to intensive animal movement both as a normal routine of the pastoral husbandry system and for the purpose of trade (Jemberu et al., 2016a).

Serological studies on FMD in Ethiopia indicated that the disease is endemic in the country. According to Ayelet et al. (2012) the overall seroprevalence of FMD in Ethiopia is $10.5 \%$ with the highest seroprevalence was detected in samples from Oromia (20.7\%); the highest seropositivity was obtained from the Eastern zone of the Tigray region with $41.5 \%$; followed by the Guji zone of Oromia and the Yeka district of Addis Ababa with 32.7 and 30\%, respectively. Seroprevalence of FMD is higher in pastoral areas (Rufael et al., 2008; Mohamoud et al., 2011; Molla, 2009). Researchers from different parts of the country reported different figure, $11.8 \%$ in Amhara region (Mesfinie et al., 2019), 14.5\% in bulls in central Ethiopia (Alemayehu et al., 2014), 24.6\% in Southern Ethopia (Mekonen et al., 2011), 21\% in Borena (Rufael et al., 2008), 9\% in Western Ethiopia (Beyene et al., 2015), 21.4\% in Kellem Wollega zone (Desissa et al., 2014), 8.01\% in Diredawa (Abunna et al., 2013), $14.05 \%$ in Somalia regional state (Mohamoud et al., 2011), 8.2 in South Omo (Molla, 2009), 5.6\% in Afar (Jembere, 2008).

Temporal distribution: Neither a significant long-term trend nor a seasonal pattern was identified in the incidence of district level FMD outbreaks from 2007-2012. But there were however, variations in the incidence of outbreaks in the different years. A higher incidence was observed in the years 2007/2008 and 2011/2012, indicating the possibility of an epidemic pulse every 4 years (Jemberu et al., 2016a).

However, as the MoLF, division of epidemiology directorate disease outbreaks report summary shows that FMD occurs at any time of the year however, the highest outbreaks of the disease are observed during extreme dry seasons of the years which is January to march. Various researchers reported that this might be associated with factors such as drought. During dry seasons, especially, pastoralists are obliged to move their herds long distances in search of pasture and water which exacerbated transmission of highly contagious diseases like FMD at herd gathering sites or communal points (Molla, 2009). On the other hand in most highland parts of the country during rainy seasons of the year wide areas of farm land is planted with crops. During this time huge numbers of domestic animals are kept on confined small plots of communal grazing lands that could favor occurrence and transmission of the disease (Aman, 2018). For example, according to Tadesse et al. (2019) study outbreak of FMD was occurred in Estie district of amhara region starting at the end of Jully and the outbreak stays up to December, the same study also reported that the outbreak of FMD was occurred at Enfranz in Godar Zuria district with the period from November to February.

Associated risk factors: Production system, presence of a major livestock market and/or route, adjacency to a national park or wild life sanctuary and animal densities, age and agroecology are significantly associated with the risk of FMD outbreaks in endemic areas. Districts that are characterized mainly by market oriented cattle production were more affected than districts with primarily subsistence systems (Jemberu et al., 2016a; Mesfinie et al., 2019). This could be associated with trade and animal movements. Livestock movement has been shown to be one of the most important risk factors for FMD in endemic countries (Fasina et al., 2013). In tropical endemic areas where high temperature and low humidity disfavor airborne transmission, it is suspected that the main mode of transmission of FMD is through contact of infected and susceptible animals (Sutmoller et al., 2003) that would be facilitated by uncontrolled animal movement.

Adjacency to a national park or sanctuary is associated with a higher district level outbreak incidence (Jemberu et al., 2016a). A similar association was reported in other countries (Bronsvoort et al., 2004; Ayebazibwe et al., 2010). Although, many wild ungulates are known to be susceptible to FMD, their role in the epidemiology of FMD is considered less significant, except for the African buffalo. The association between FMD incidence and wildlife parks could therefore be primarily related to buffalos which are known to be a natural reservoir for SAT viruses (Thomson et al., 2003). It is due to this fact that SAT serotypes were rst reported in the Southern and Southwestern Ethiopia where national parks with buffalo populations (Omo and Gambella national parks) are found (Jemberu et al., 2016a).

Production system is the major risk factor for the epidemiology of foot and mouth disease in Ethiopia. Accordingly, pastoral production system was identified to be the major risk factor for FMD occurrence. Higher prevalence of the disease in pastoral areas could be attributable to unrestricted high herd mobility, continuous contact and intermingling of different herds at water points and communal grazing areas (Megersa et al., 2009). Highly significant difference in seroprevalence 
Agric. J., 14 (5): 79-93, 20190

$(\mathrm{p}<0.01)$ was observed between pastoral and sedentary systems with 16 times higher likelihood of disease occurrence in pastoral than sedentary herds (Jemberu et al., 2016a).

Density of animals kept together with different species is also a risk factor for the occurrence of FMD outbreak. One study in Southern Ethiopia showed that cattle herds kept with sheep and goat combination were at 5.1 times higher risk of being infected than those with either of the species or alone $(\mathrm{p}=0.048$. $)$ The significant association between increased stock composition and seroprevalence suggests the role of other animals as reservoir for susceptible species (Megersa et al., 2009).

Altitude ranges have shown an inverse linear relationship with the occurrence of the FMD prevalence. Negative association of seropositivity with altitude range could be related to inverse relationship of number of animals per holdings and increasing altitude. Scarcity of feed and water resources in the lowland increase animal movement and aggregations of animals at water points (Megersa et al., 2009: Bayissa et al., 2011).

Animal factors also play significant role in the occurrence of a disease. According to Bayissa et al that increase in age has positively associated with the prevalence of FMD. As age increases, the chance of exposure to the disease increases. FMD was significantly varied with ages, the risk of seropositivity being 2.8 and 2.3 times higher in the adult and maturing animals, respectively than younger animals (Bayissa et al., 2011; Jemberu et al., 2016a; Mesfinie et al., 2019).

Distribution of FMDV serotypes: FMD serotypes are not uniformly distributed in the regions of the world where the disease still occurs. For example, the cumulative incidence of FMD serotypes show that six of the seven serotypes of FMD (O, A, C, SAT-1, SAT-2, SAT-3) have occurred in Africa while Asia contends with four sero-types (O, A, C, Asia-1) and South America with only three $(\mathrm{O}, \mathrm{A}, \mathrm{C})$. Periodically there have been incursions of Types SAT- 1 and SAT-2 from Africa into the Middle East (Rweyemamu et al., 2008).

In Ethiopia different researchers detected 5 of the 7 FMDV serotypes (O, A, C, SAT 1 and SAT 2). Serotype O predominated, followed by serotype A; type $C$ was not recognized after 1983. Phylogenetic analysis of virus protein 1 sequences indicated emergence of a new topotype within serotype O, East Africa 4. In 2007, serotype SAT1 was detected in Ethiopia (Legesse et al., 2013) and formed a new distinct topotype (IX) and serotype SAT2 reappeared after an apparent gap of 16 years. The diversity of viruses highlights the role of this region as a reservoir for FMD virus and their continuing emergence in Ethiopia will greatly affect spread and consequent control strategy of the disease on this continent(Ayelet et al., 2009).

Geographically, the outbreaks were widely distributed. Most of the strains were distributed within central Ethiopia including the Addis Ababa administrative region; the rest were in Ahmara and Tigray in the North, Dire Dawa in the Northeast, Beneshangul-Gumuz bordering Sudan in the West and Southern Nations Nationalities and Peoples Region bordering Kenya and Sudan in the South (Fig. 2). In Eastern Ethiopia, poor veterinary services and inaccessibility to the area could have resulted in the lack of samples submitted (Ayelet et al., 2009).

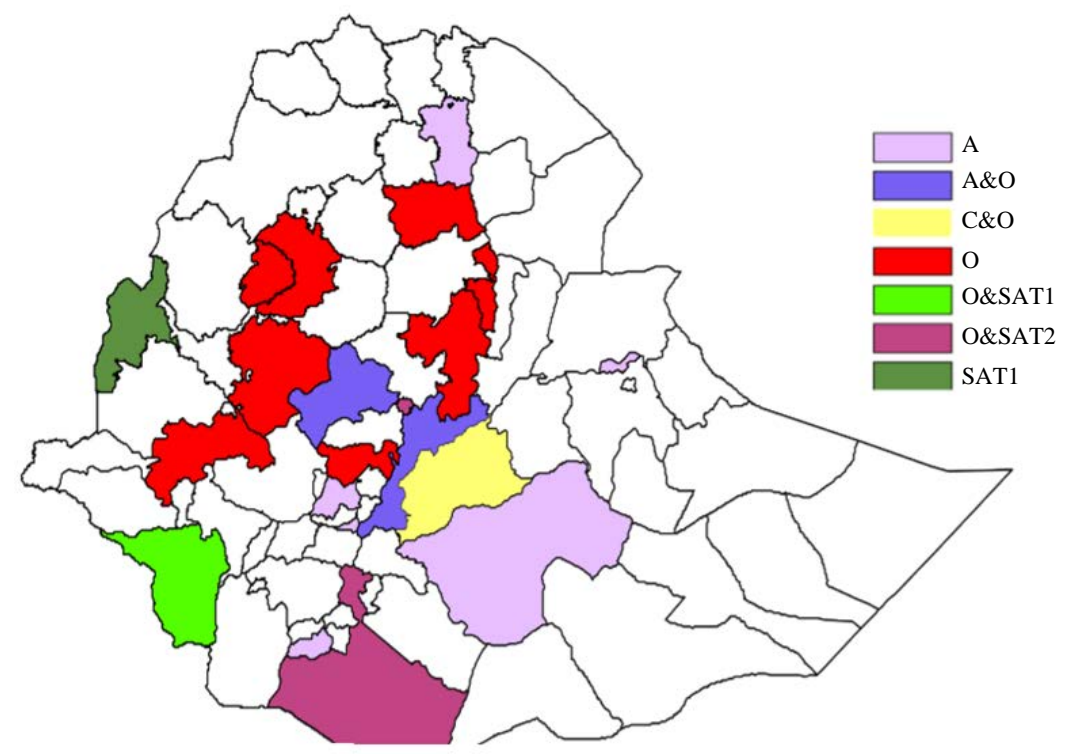

Fig. 2: Distribution of FMDV serotypes in Ethiopia from 1981-2007 (Ayelet et al., 2009) 
Agric. J., 14 (5): 79-93, 20190

Table 1: Summary of serotypes of FMDV circulating in Ethiopia reported until 2019

\begin{tabular}{|c|c|c|c|}
\hline Serotype & Year & Place & Reference \\
\hline \multirow[t]{3}{*}{$\mathrm{A}$ and $\mathrm{O}$} & 2018/19 & $\begin{array}{l}\text { Oromia (Guduru, Adea Berga and Wolmera), SN NPR (Shashogo) and Tigray } \\
\text { (Siasi Stida Imba, Ambalage, Raya Alamata, Korem, Hintalo Wajirat, Kilte } \\
\text { Awilailo and Asgede Tsibala) }\end{array}$ & Tikuye, 2019 \\
\hline & 2016/17 & $\begin{array}{l}\text { Oromia (Meki, Bishoftu), Amhara (Shewarobit, Albuko, Werebabu) and AA } \\
\text { (Bole sub city) }\end{array}$ & Yirgalem, 2018 \\
\hline & 2016/17 & $\begin{array}{l}\text { Oromia (Mulo, Aleltu, Kimbibit, Wochale, Adea Wereda) and AA } \\
\text { (Kolfe Keraniyo) }\end{array}$ & Sissay et al., 2017 \\
\hline $\mathrm{O}$ and SAT2 & 2016/17 & $\begin{array}{l}\text { AA (Akaki, Bole and Yeka sub cities), Oromia (Modjo, Koka, Alemtena and } \\
\text { Birbirsa) and Amhara( Angolela and Gudoberet) }\end{array}$ & Wondwossen, 2017 \\
\hline $\mathrm{O}, \mathrm{A}, \mathrm{SAT} 1$ and SAT2 & 2016/17 & Oromia(Wolmera, Adea Berga, Mulo and Kimbibit) and AA(Kolfe Keranyo) & \\
\hline A, $\mathrm{O}$ and SAT2 & $\begin{array}{l}2007-2012 \\
2015 / 16\end{array}$ & $\begin{array}{l}\text { AA, Oromia, SNNPR, Amhara, Benishangul Gumuz, Harar, Tigray } \\
\text { Oromia (Guna,Ludohitosa, Adama and Boset) and AA(Kolfe) }\end{array}$ & Jemberu et al., 2016a, b \\
\hline \multirow[t]{2}{*}{$\mathrm{O}$} & 2011/12 & $\begin{array}{l}\text { Oromia (Alage, Adamitulu and Bishoftu), AA (Akaki Kaliti) and Tigray } \\
\text { (Mekele University farm, Enderta chelokot Debri and aynalem farm) } \\
\text { and Amhara (Debre berhan) }\end{array}$ & $\begin{array}{l}\text { (Menda et al., 2014; } \\
\text { Kassaw et al., 2013) }\end{array}$ \\
\hline & 2017/18 & Estie district and Gondar Zuria district of Amhara region & Tadesse et al., 2019 \\
\hline \multirow[t]{3}{*}{$\mathrm{O}$ and SAT2 } & 2010/11 & Bishoftu & Belay and Muktar, 2015 \\
\hline & 2009/10 & AA, Debre Zeit, Debre Berhan and Sululta & Hailu et al., 2017 \\
\hline & 1988-1991 & AA, Eritrea, Wellega, Harerghe, Dire Dawa and Borena & Roeder et al., 1994 \\
\hline $\mathrm{O}$ and SAT1 & 2007/08 & Girar Jarso, Yabelo, Surma, Maji Ankasha and Guagusa & Legesse et al., 2013 \\
\hline $\mathrm{O}, \mathrm{A}, \mathrm{C}, \mathrm{SAT} 1$ and 2 & $1981-2007$ & AA, Amhara, Tigray, Benishangul Gumuz, Oromia and SNNPR & Ayelet et al., 2009 \\
\hline
\end{tabular}

In central Ethiopia, four serotypes namely serotype A, O, SAT1 and SAT2 are responsible for most outbreaks reported. Serotype O is highly prevalent and a dominant serotype causing an outbreak in central Ethiopia (Motuma, 2017; Sulayeman et al., 2018); serotype A, O and SAT2 were reported from Addis Ababa, SAT1 was isolated from Adea Berga district (Urge et al., 2019). Wondwossen (2017) reported serotype $\mathrm{O}$ as a cause of outbreak in Debre Berhan and East Shewa. Proportion of FMDV serotypes circulating indicates that serotype O>A > SAT1>SAT2 (Urge and Gizaw, 2018). Serotype C was reported lastly from the samples collected in 1983, since, then it has not been isolated and this indicates that type $\mathrm{C}$ seems to have disappeared from Ethiopia (Gelaye et al., 2009).

Serotype $\mathrm{O}$ is endemic in different areas of Northern Ethiopia. It was reported from the outbreak in different farms in Tigray regional state (Kassaw et al., 2013; Tikuye, 2019). In Amhara region this serotype was identified from outbreaks in Estie district of South Gondar zone and Gondar Zuria district (Tadesseet al., 2019) and in other parts of Amhara region (Ayelet et al., 2009; Yirgalem, 2018).

Studies on outbreaks in Southern Ethiopia indicated that serotype $O$ is endemic in the area (Tikuye, 2019). In addition to serotype $\mathrm{O}$ there is a report of SAT1 and SAT2 serotypes in outbreaks occurred in Southern Ethiopia. The first recorded occurrence of FMDV type SAT1 in Ethiopia was identified from a bovine sample collected in November, 2007 from the Mizan Teferi area bordering Kenya. The first isolation of SAT 2 was in 1989 from a sample collected from cattle raised on Leben Ranch, Borena zone in Southern Ethiopia (Ayelet et al., 2009).

In Western Ethiopia there is a report of serotype $\mathrm{O}$ as a cause for outbreak particularly in Horo
Guduru Wellega zone of Oromia region (Tikuye, 2019). SAT2 was recorded again in 2007, after an apparent gap of 16 years from a bovine sample collected from Bambas, Beneshangul-Gumuz, Ethiopia bordering Sudan. SAT2 may have been recently introduced by animal movement across the border with Sudan because SAT2 is endemic to Sudan (Vosloo et al., 2002). Two explanations are possible for this gap: the virus may present in Ethiopia but has not been detected because all outbreaks are not reported or investigated and/or serotype SAT2 viruses circulate sub clinically in Ethiopia, possibly in wildlife (Ayelet et al., 2009).

Sufficient studies are not conducted in Eastern Ethiopia, although, serotype $\mathrm{O}$ is reported from outbreaks around the area. Studies indicated that this serotype was isolated from outbreak samples in Haremaya (Negusssie et al., 2011), Harar (Jemberu et al., 2016a, b) and Dire Dawa (Ayelet et al., 2009). The serotypes of FMDV circulating in Ethiopia until 2019 are summarized as in Table 1.

Distribution of serotypes by host: Foot and mouth disease virus serotypes O, A, C, SAT- 1 and SAT-2 were identified from bovine, swine, ovine and caprine in Ethiopia and these serotypes were responsible for FMD outbreaks in different parts of Ethiopia (Gelaye et al., 2009). Cattle were found to be infectedwith all circulating serotypes of FMDV whereas swine had been only by serotype O (Gelaye et al.., 2005; Nigussie, 2010). SAT1, SAT2 and O serotypes were also reported from small ruminants (Tefera, 2010).

Topotypes of FMDV in Ethiopia: Topotype is used to describe the presence of genetically and geographically 
Agric. J., 14 (5): 79-93, 20190

Table 2: Topotypes of FMDV in Ethiopia

\begin{tabular}{|c|c|c|c|c|}
\hline Serotype & Topotype & Genotype & Year & References \\
\hline \multirow[t]{8}{*}{$\mathrm{O}$} & EA-1 & & $1979-2001$ & \\
\hline & EA-3,EA-4 & & $1981-2007$ & Ayelet et al., 2009 \\
\hline & & & $2018 / 19$ & Tikuye, 2019 \\
\hline & EA-3 & & 2017/18 & Yirgalem, 2018 \\
\hline & & & 2008/09 & \\
\hline & & & 2009/10 & Hailu et al., 2017 \\
\hline & & & 2011/12 & Menda et al., 2014; Kassaw et al., 2013 \\
\hline & EA-4 & & 2016/17 & Wondwossen, 2017 \\
\hline \multirow[t]{4}{*}{ A } & African & & $1981-2007$ & Ayelet et al., 2009 \\
\hline & & G-VII & $2008 / 09$ & \\
\hline & & IV & 2015/16 & Sulayman et al., 2018 \\
\hline & & G-I & 2017/18 & Yirgalem, 2018 \\
\hline $\mathrm{C}$ & Africa & & 1984 & Ayelet et al., 2009 \\
\hline SAT1 & IX & & $1981-2007$ & Ayelet et al., 2009 \\
\hline \multirow[t]{5}{*}{ SAT2 } & XIV & & 1991 & Ayelet et al., 2009 \\
\hline & IV & & 1989 & Ayelet et al., 2009 \\
\hline & XIII & & 2007 & Ayelet et al., 2009 \\
\hline & XIII & & 2009/10 & Hailu et al., 2017 \\
\hline & VII & Alx-12 & 2015/16 & Sulayman et al., 2018 \\
\hline
\end{tabular}

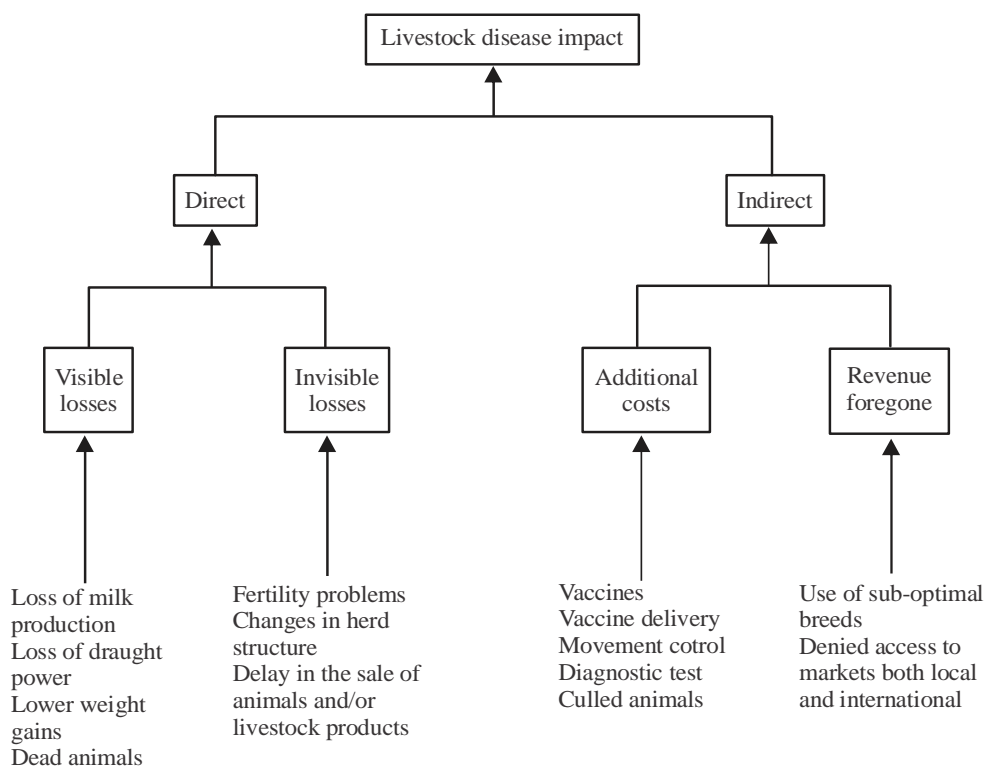

Fig. 3: Impacts of foot and mouth disease (Rushton, 2009)

distinct evolutionary lineages (Samuel and Knowles, 2001). Previous studies have provided evidence for the presence of different topotypes of FMDV serotypes from the five serotypes $(\mathrm{O}, \mathrm{A}, \mathrm{C}, \mathrm{SAT} 1$ and SAT2) reported in Ethiopia from samples collected from different outbreaks occurred from 1979-2019 (Table2).

Currently available vaccine type: In Ethiopia trivalent inactivated vaccine manufactured from locally isolated FMDV serotypes O, A and SAT2 is produced by National Veterinary Institute (NVI) (Tesfaye, 2014). The virus is propagated from cell culture and absorbed into aluminum hydroxide gel and inactivated with $0.3 \%$ formal dehyde and adjuvinated with saponin. The recommended amount for cattle is $4 \mathrm{~mL}$ per head and administered subcutaneously, preferably in the dewlap region. In order to protect the cattle, two injections at 6 months interval are recommended. Immunity develops 2-3 weeks after vaccination and may last for 1 year (DACA., 2004). Since, the virus can not cross protect each other the vaccine should be developed in such a way that incorporates all the serotypes prevalent in Ethiopia.

Economic impacts of FMD in Ethiopia: The economic impact of FMD is colossal globally, although, it causes low mortality of animals. This impact can be divided into two components: direct impacts due to production losses and change in herd structure and indirect impacts due to FMD control costs, limited access to market and limited use of new production technologies (Fig. 3). The FMD impacts in terms of visible production losses and vaccination cost in endemic countries can cause 
losses of >USD 1.5 billion per year (Knight-Jones and Rushton, 2013). The economic impact of FMD to the dairy sector is substantially high due to subsequent milk loss, mortality and premature culling (Beyi, 2012). FMD hinders the trading of milk, meat, animals and other agricultural products (Knight-Jones and Rushton, 2013). The direct and indirect losses associated with FMD are in terms of mortality, morbidity and milk production, trade losses, growth rate and abortion (Chakraborty et al., 2014).

Foot and mouth disease causes the highest economic impact on the poorest countries like Ethiopia where the livelihood of most of the people depends directly on livestock. It reduces herd fertility leading to less efficient herd structure, discourages the use of FMD susceptible high productivity breeds, causes trade bans and high control costs (Knight-Jones and Rushton, 2013; Jemberu et al., 2016b). In Ethiopia FMD is posing a major threat thereby causing substantial economic losses through morbidity and mortality (Abdela, 2017).

Direct impacts: Direct costs include visible losses which comprises milk production losses, draft power losses, weight losses and death losses and invisible losses which include fertility problem that lead to herd structure and a delay in the sale of the animal and/or livestock products (Knight-Jones and Rushton, 2013). Jemberu et al. (2016b) reported that the estimated herd level economic losses of FMD outbreak in cattle, arising from milk loss, mortality and draft power loss is on average 76 USD per affected herd, 9.8 USD per head in crop-livestock mixed system and 174 USD per affected herd and 5.3 USD per head in the pastoral system. In another study, the overall short-term farm level direct loss due to FMD outbreak in an urban dairy farm was estimated to $€ 1962$ (Beyi, 2012). In Ethiopia the total annual production losses caused by FMD is estimated to be in the range of 783-1958 (1270) million Birr. Most of the losses are due to reduction of milk production (Jemberu et al., 2014).

According to Bayissa et al.(2011) study acute phase of FMD infection resulted in reduction of about $0.5-1.5 \mathrm{~L}$ of milk per day per lactating cow for 25.5 days. This loss of milk was accounted about $73.3 \%$ of milk which was supposed to be produced within those days but only $7.7 \%$ of total milk production of a lactating cow per lactation period. This high temporary loss of milk possibly exacerbated the shortage of milk production during dry seasons in which mostly outbreaks were occurred (Bayissa et al., 2011; Jibat et al., 2013). Cows developing heat intolerance syndrome after acute infection gave an average $0.67 \mathrm{~L}$ for 3.8 months and their calving interval prolonged about 12 months (Bayissa et al., 2011). Permanent daily milk yield reductions, prolongation of calving interval and vulnerability for drought are the consequences of developing heat-intolerance syndrome after recovery of proportion of cattle from acute-phase FMD infection. Jemberu et al. (2016b) estimated the costs FMD due to reduction of milk production in Ethiopia be on average 665 (278-1268) million Birr annually.

Ethiopia losses 308 (95-589) million Ethiopian Birr due to impact of FMD on draft power (Jemberu et al., 2016b). Studies in Southern Ethiopia indicated that FMD-infected oxen remain off plough for one season when outbreaks occur in cropping time whereas heat-intolerant oxen are no longer used for traction. Thus, agro-pastoralists were compelled to borrow from their clan members freely or rent oxen or plough a day for owner of oxen for 1 day to work with them (Bayissa et al., 2011). It causes loss of 1-15 with mean of 5 effective working days which can be estimated to loss 3-41(15) USD/ox in Ethiopia (Jemberu et al., 2014) in the crop-livestock mixed production system (MCL) due to the renting of replacement oxen for plowing and threshing.

Mortality losses are also another important economic losses caused by FMD. The largest production losses at animal level are mortality losses due to the death of the animal. In Ethiopia it is estimated to cause a cost of more than 300 million Birr per year (Jemberu et al., 2016b). Jemberu et al. (2014) also reported animal level mortality losses of USD 129 in MCL production system and USD 151 in pastoral production system due to a specific FMD outbreak.

Indirect impacts: Indirect economic impacts due to FMD include additional costs (control costs, surveillance costs, vaccination costs) and revenue forgone which include limited access to market and limited use of new production technologies and externalities (Knight-Jones and Rushton, 2013). Some of these cost categories are excessively difficult to quantify like use of less productive but less susceptible breeds and the restriction of market access because these impacts cannot be exclusively attributed to foot and mouth disease only(Jemberu et al., 2016b).

According to Wagari (2016) about 71,026.8 USD losses was recorded in terms of economic impact on export earnings in Ethiopia. In 2011 the total annual economic loss due to bull's rejection from international market was estimated to be 3,322,269 USD (Alemayehu et al., 2014). Although, it is not fully estimated, the export costs of foot and mouth disease are moderate in Ethiopia. Its impact on export earnings is estimated to be 34-46 million Birr with an average of 40 milllion Birr (Jemberu et al., 2016b).

Control costs like vaccination, outbreak investigation costs, treatment costs and surveillance costs are important costs associated with the disease. These costs are enormous with an estimated 2.35 billion doses of FMD vaccine administered in the world every year at a cost of 0.4-3 USD or occasionally $\$ 9$ per dose including delivery 
Agric. J., 14 (5): 79-93, 20190

and application (Sutmoller et al., 2003; Barasa et al., 2008; Forman et al., 2009). Due to the short duration of immunity induced by FMD vaccines, ongoing control programmer's vaccinate cattle at least two times a year and sheep and goats once a year; limiting resources available to combat other diseases (Knight-Jones and Rushton, 2013). Jemberu et al. (2016a, b) estimated that the control costs in Ethiopia reaches more than 44 million Ethiopian Birr. Movement restrictions disrupt the normal flows of animals and can result in welfare problems if access to housing and grazing is prevented. In the UK 2001 this accounted for one third of animals culled (Mansley et al., 2011). A herd level cost of treatment of USD 67 per infected farm was reported in central Ethiopia (Beyi, 2012).

\section{CONCLUSION}

Foot and mouth disease is a highly contagious and economically important trans-boundary animal disease which affects cloven hoofed animals and is distributed worldwide. Serotypes A and O have the highestworldwide distribution. Serotypes SAT 1, 2 and 3 are currently restricted to Africa only and Asian 1 to Asia. Serotype O, A, SAT1 and SAT2 are currently circulating in Ethiopia with serotype $\mathrm{O}$ being the predominantly distributed serotype in the country. Serotype $C$ is extinct from the country, since, 1984, when it is reported from Ethiopia. Foot and mouth disease outbreaks are reported every year and in all regions with the most frequent outbreak occurrence being in the central, Southern and Southeastern Ethiopia and in dry seasons. FMD is the most economically important disease in Ethiopia and can cause both direct and indirect impacts on the economy. These economic losses are due to production losses (i.e., reduction of milk production, loss of draft power, mortality), restriction of export, control costs and prevention costs.

\section{RECOMMENDATIONS}

Therefore, based on the above information the following points are recommended: The epidemiology of FMD in Ethiopia along with the associated risk factors should be studied further in different areas nationally. Control of animal's movement should be strengthened to limit spreading of serotypes.

Molecular characterization of the serotypes present, especially in pastoral areas should be thoroughly conducted. The vaccine present in Ethiopia is not effective for all the serotypes present in the country, so, vaccines should be developed according to the strains prevalent.

\section{ACKNOWLEDGEMENT}

Above all thanks goes to ALLAH, the most gracious, the most merciful, lord of the universe for his innumerable favors, giving health and vigor to me during the study time.

Next, I would like to thank my advisor Dr. Belege Tadesse for his unreserved help, constructive advice and time commitment to correct this seminar paper. I also thank him for his genuine and energetic encouragement, suggestion, insight and scientific and professional guidance.

I want to extend my sincerely thanks to Ethiopian Institute of Agricultural Research, Werer Agricultural research center for the general support during the courses of entire education. My special thanks go to my families who were behind the successes of my education. I thank you very much.

\section{List of abreviations:}

$\% \quad:$ Percent

${ }^{\circ} \mathrm{C} \quad$ : $\quad$ Degree Celsius

AA : Addis Ababa

UTR : Untranslated Region

BHK-21 : Baby Hamster Kidney 21 day

BLAST : Basic Local Alignment Search Tool

cDNA : Complementary DNA

CFT : Complement Fixation Tests

CPE : Cytopathic Effect

DNA : Deoxyribose Nucleic Acid

EA : East Africa

ELISA : Enzyme-Linked Immunosorbent Aassays

FAO : Food and Agriculture Organization

FMD : Foot and Mouth Disease

FMDV : Foot and Mouth Disease Virus

G : Genotype

$\mathrm{Kb} \quad$ : Kilo base pair

MCL : $\quad$ Mixed Crop Livestock

MoARD : Ministry of Agriculture and Rural Development

MoLF : Ministry of Livestock and Fisheries

NSP : Non Structural Protein

$\mathrm{Nt} \quad$ : Nucleotide

NVI : National Veterinary Institute

OIE : : World Animal Health Organization

PCR : Polymerase Chain Reaction

RNA : Ribonucleic Acid

rRT-PCR : Real Time Reverse Transcriptase Polymerase Chain Reaction

RT-PCR : Reverse Transcriptase Polymerase Chain Reaction

SAT : South Africa Territories

SNNPR : Southern Nations, Nationalists and Peoples Region

SP : Structural Protein 
Agric. J., 14 (5): 79-93, 20190

UK : United Kingdom

USD : United States Dollar

VNT : Virus Neutralization Test

VP : Virus Protein

\section{REFERENCES}

Abdela, N., 2017. Sero-prevalence, risk factors and distribution of foot and mouth disease in Ethiopia. Acta Trop., 169: 125-132.

Abunna, F., S. Fikru and T. Rufael, 2013. Seroprevalence of Foot and Mouth Disease (FMD) at Dire Dawa and its surroundings, Eastern Ethiopia. Global Vet., 11: 575-578.

Admassu, B., K. Getnet, A. Shite and S. Mohammed, 2015. Review on foot and mouth disease: Distribution and economic significance. Acad. J. Anim. Dis., 4: 160-169.

Alemayehu, G., G. Zewde and B. Admassu, 2014. Seroprevalence of Foot and Mouth Disease (FMD) and associated economic impact on Central Ethiopian cattle feedlots. J. Vet. Med. Anim. Health, 6: 154158.

Alexandersen, S., Z. Zhang, A.I. Donaldson and A.J.M. Garland, 2003. The pathogenesis and diagnosis of foot-and-mouth disease. J. Comp. Pathol., 129: 1-36.

Aman, E., 2018. Review on current status of FMD in Ethiopia: Spatiotemporal distribution, frequency and prevalence. Rep. Opin., 10: 60-68.

Awan, F.N., 2009. Epidemiology of foot and mouth disease in buffaloes of Punjab province. Ph.D. Thesis, University of Veterinary and Animal Sciences, Lahore, Pakistan.

Ayebazibwe, C., K. Tjornehoj, F.N. Mwiine, V.B. Muwanika, A.R.A. Okurut, H.R. Siegismund and S. Alexandersen, 2010. Patterns, risk factors and characteristics of reported and perceived Foot-andMouth Disease (FMD) in Uganda. Trop. Anim. Health Prod., 42: 1547-1559.

Ayelet, G., E. Gelaye, H. Negussie and K. Asmare, 2012. Study on the epidemiology of foot and mouth disease in Ethiopia. Rev. Sci. Tech. Off. Int. Epiz., 31: 789798.

Ayelet, G., M. Mahapatra, E. Gelaye, B.G. Egziabher and T. Rufeal et al., 2009. Genetic characterization of foot-and-mouth disease viruses, Ethiopia, 1981-2007. Emerg. Infect. Dis., 15: 1409-1417.

Barasa, M., A. Catley, D. Machuchu, H. Laqua, E. Puot, D.T. Kot and D. Ikiror, 2008. Foot-and-mouth disease vaccination in South Sudan: Bene t-cost analysis and livelihoods impact. Transbound. Emerg. Dis., 55: 339-351.

Bayissa, B., G. Ayelet, M. Kyule, Y. Jibril and E. Gelaye, 2011. Study on seroprevalence, risk factors and economic impact of foot-and-mouth disease in Borena pastoral and agro-pastoral system, Southern Ethiopia. Trop. Anim. Health Prod., 43: 759-766.
Belay, H. and Y. Muktar, 2015. Isolation and identification of foot and mouth disease virus from clinically infected cattle in Ada Veterinary Clinic. Am. Eurasian J. Sci. Res., 10: 368-374.

Beyene, B., T. Tolosa, T. Rufael, B. Hailu and T. Teklue, 2015. Foot and mouth disease in selected districts of western Ethiopia: Seroprevalence and associated risk factors. Rev. Sci. Tech. Off. Int. Epiz., 34: 939-952.

Beyi, A., 2012. Costs and benefits of foot and mouth disease vaccination practices in commercial dairy farms in Central Ethiopia. M.Sc. Thesis, Wageningen University, Wageningen, The Netherlands.

Bouma, A., A.R.W. Elbers, C. Bartels, A.D. Koeijer and P. Vellema et al., 2001. The epidemic of foot-andmouth disease in the Netherlands in 2001. Proceedings of the 14th Annual Meeting of VEEC, Wageningen, December 12, 2001, Wageningen University, Wageningen, pp: 9-16.

Bronsvoort, B.M.D.C., A.D. Radford, V.N. Tanya, C. Nfon, R.P. Kitching and K.L. Morgan, 2004. Molecular epidemiology of foot-and-mouth disease viruses in the Adamawa province of Cameroon. J. Clin. Microbiol., 42: 2186-2196.

Chakraborty, S., N. Kumar, K. Dhama, A.K. Verma and R. Tiwari et al., 2014. Foot-and-mouth disease, an economically important disease of animals. Adv. Anim. Vet. Sci., 2: 1-18.

Chase-Topping, M.E., I. Handel, B.M. Bankowski, N.D. Juleff and D. Gibson et al., 2013. Understanding foot-and-mouth disease virus transmission biology: Identification of the indicators of infectiousness. Vet. Res., 44: 1-10.

DACA., 2004. Standard treatment guidelines for veterinary practice. Drug Administration and Control Authority of Ethiopia (DACA), Addis Ababa, Ethiopia.

Deb, R., S. Chakraborty, B. Veeregowda, A.K. Verma, R. Tiwari and K. Dhama, 2013. Monoclonal antibody and its use in the diagnosis of livestock diseases. Adv. Biosci. Biotechnol., 4: 50-62.

Desissa, F., D. Tura, B. Mamo and T. Rufae, 2014. Epidemiological study on foot and mouth disease in cattle: Seroprevalence and risk factor assessment in Kellem Wollega Zone, West Ethiopia. Afr. J. Agric. Res., 9: 1391-1395.

Ding, Y.Z., H.T. Chen, J. Zhang, J.H. Zhou and L.N. Ma et al., 2013. An overview of control strategy and diagnostic technology for foot-andmouth disease in China. Virol. J., Vol. 10. 10.1186/1743-422X-10-78.

Fasina, F.O., D.R. Connell, O.A. Talabi, D.D. Lazarus and G.A. Adeleke et al., 2013. Foot-and-mouth disease virus strains and examination of exposure factors associated with seropositivity of cattle herds in Nigeria during 2007-2009. Preventive Vet. Med., 109: 334-342. 
Agric. J., 14 (5): 79-93, 20190

Forman, S., F.L. Gall, D. Belton, B. Evans and J.L. Francois et al., 2009. Moving towards the global control of foot and mouth disease: An opportunity for donors. Rev. Sci. Tech. Off. Int. Epiz., 28: 883-896.

Gelaye, E., B. Beyene and G. Aylete, 2005. Foot and mouth disease virus serotype identified in Ethiopia. Ethiop. Vet. J., 9: 75-80.

Gelaye, E., G. Ayelet, T. Abera and K. Asmare, 2009. Seroprevalence of foot and mouth disease in Bench Maji zone, Southwestern Ethiopia. J. Vet. Med. Anim. Health, 1: 5-10.

Grubman, M.J. and B. Baxt, 2004. Foot and mouth disease. Clinical Microbiol. Rev., 17: 465-493.

Hailu, D., B. Abera, D. Lemma, E. Eticha and D. Deferes, 2017. Out break investigation and epidemiology of foot-and-mouth disease virus circulating in central areas of Ethiopia. Acad. J. Anim. Dis., 6: 75-82.

Jamal, S.M. and G.J. Belsham, 2013. Foot-and-mouth disease: Past, present and future. Vet. Res., 44: 1-14.

Jembere, S., 2008. Participatory epidemiology and seroprevalence of Foot and Mouth Disease in Afar Pastoral region, Ethiopia. M.Sc. Thesis, Addis Ababa University, Addis Ababa, Ethiopia.

Jemberu, W.T., M. Mourits, J. Rushton and H. Hogeveen, 2016a. Cost-benefit analysis of foot and mouth disease control in Ethiopia. Preventive Vet. Med., 132: 67-82.

Jemberu, W.T., M.C. Mourits, T. Woldehanna and H. Hogeveen, 2014. Economic impact of foot and mouth disease outbreaks on smallholder farmers in Ethiopia. Preventive Vet. Med., 116: 26-36.

Jemberu, W.T., M.C.M. Mourits, M. Sahle, B. Siraw, J.C.M. Vernooij and H. Hogeveen, 2016b. Epidemiology of Foot and Mouth Disease in E thiopia: A retrospective analysis of district level outbreaks, 2007-2012. Transboundary Emerging Dis., 63: e246-e259.

Jibat, T., B. Admassu, T. Rufael, M.P.O. Baumann and C.J. Potzsch, 2013. Impacts of foot-and-mouth disease on livelihoods in the Borena Plateau of Ethiopia. Pastoral. Res. Policy Pract., Vol. 3, 10.1186/2041-7136-3-5

Kassaw, K., B. Afera, K. Amasalu and D. Hussien, 2013. Serotype identification and molecular characterization of foot and mouth disease in and around Mekelle, Tigray region. Global Veterinaraian, 11: 390-394.

Kitching, R.P. and G.J. Hughes, 2002. Clinical variation in foot and mouth disease: Sheep and goats. Rev. Sci. Tech., 21: 505-512.

Knight-Jones, T.J.D. and J. Rushton, 2013. The economic impacts of foot and mouth disease-What are they, how big are they and where do they occur? Prev. Vet. Med., 112: 161-173.
Lefebvre, D.J., J. Neyts and K.D. Clercq, 2010. Development of a foot and mouth disease infection model in severe combined immunodeficient mice for the preliminary evaluation of antiviral drugs. Transboundary Emerging Dis., 57: 430-433.

Legesse, Y., Y. Asfaw, M. Sahle, G. Ayelet, S. Jenberie and H. Negussie, 2013. First confirmation of foot and mouth disease virus serotype SAT- 1 in cattle and small ruminants in Ethiopia in 2007/08. Trop. Anim. Health Prod., 45: 1265-1267.

Longjam, N., R. Deb, A.K. Sarmah, T. Tayo, V.B. Awachat and V.K. Saxena, 2011. A brief review on diagnosis of foot-and-mouth disease of livestock: Conventional to molecular tools. Vet. Med. Int., Vol. 2011 10.4061/2011/905768

Ludi, A., V. Mioulet, N.J. Knowles and D.P. King, 2017. Laboratory Diagnostic Methods to Support the Surveillance and Control of Foot-and-Mouth Disease. In: Foot-and-Mouth Disease Virus: Current Research and Emerging Trends, Sobrino, F. and E. Domingo (Eds.). Caister Academic Press, UK., ISBN: 978-1910190-52-4, Pages: 275-286.

Lyytikainen, T., J. Niemi, L. Sahlstrom, T. Virtanen and H. Lehtonen, 2011. The spread of Foot-and-Mouth Disease (FMD) within Finland and emergency vaccination in case of an epidemic outbreak. Evira Research Reports 1., Finnish Food Safety Authority, $\mathrm{H}$ e l s i n k i, $\quad F$ i n l a $n$ d. https://www.academia.edu/23287387/The_spread_ of_Foot-and-mouth_disease _FMD_within_ Finland_and_emergency_vaccination_in_case_of_an_epidemic_outbreak?auto=download

MARD., 2006. Foot and mouth disease control plan. Ministry of Agriculture and Rural Development Animal and Plant Health Regulatory Directorate, Addis Ababa, Ethiopia.

Mansley, L.M., A.I. Donaldson, M.V. Thrusfield and N. Honhold, 2011. Destructive tension: Mathematics versus experience-the progress and control of the 2001 foot and mouth disease epidemic in Great Britain. Rev. Sci. Tech. OIE., 30: 483-498.

Megersa, B., B. Beyene, F. Abunna, A. Regassa, K. Amenu and T. Rufael, 2009. Risk factors for foot and mouth disease seroprevalence in indigenous cattle in Southern Ethiopia: The effect of production system. Trop. Anim. Health Prod., 41: 891-898.

Mekonen, H., D. Beyene, T. Rufael, A. Feyisa and F. Abunna, 2011. Study on the prevalence of foot and mouth disease in Borana and Guji Zones, Southern Ethiopia. Vet. World, 4: 293-296.

Menda, S., S. Jenberie, H. Negussie, G. Ayelet and K. Amasalu, 2014. Molecular epidemiology of foot and mouth disease virus outbreaks in Ethiopia in 2011/2012. Acad. J. Anim. Dis., 3: 08-16. 
Agric. J., 14 (5): 79-93, 20190

Mesfinie, M., S. Nigatu, N. Belayneh and W.T. Jemberu, 2019. Sero-epidemiology of Foot and Mouth Disease in domestic ruminants in Amhara Region, Ethiopia. Front. Vet. Sci., Vol. 6, 10.3389/fvets.2019.00130

Mohamoud, A., E. Tessema and H. Degefu, 2011. Seroprevalence of bovine Foot and Mouth Disease (FMD) in Awbere and Babille districts of Jijiga zone, Somalia Regional State, Eastern Ethiopia. Afr. J. Microbiol. Res., 5: 3559-3563.

Molla, B., 2009. Epidemiological study on foot and mouth disease in cattle: Participatory appraisal and sero-prevalence in South Omo Zone of SNNPRS, South-Western Ethiopia. M.Sc. Thesis, Addis Ababa University, Addis Ababa, Ethiopia.

Motuma, D., 2017. Molecular characterization and vaccine matching test of foot and mouth disease viruses isolated from outbreak cases in cattle in selected sites of central part of Oromia, Ethiopia. M.Sc. Thesis, Addis Ababa University, Bishoftu, Ethiopia.

Murphy, M.L.P., M.A. Forsyth, G.J. Belsham and J.S. Salt, 1999. Localization of foot-and-mouth disease virus RNA by in situ hybridization within bovine tissues. Virus Res., 62: 67-76.

Musser, J.M., 2004. A practitioner's primer on foot-andmouth disease. J. Am. Vet. Med. Assoc., 224: 12611268.

Negusssie, H., M.N. Kyule, M. Yami and G. Ayelet, 2011. Outbreak investigations and genetic characterization of foot-and-mouth disease virus in Ethiopia in 2008/2009. Trop. Anim. Health Prod., 43: 235-243.

Nigussie, H., 2010. Study on molecular epidemiology of foot and mouth disease in Ethiopia. M.Sc. Thesis, Addis Ababa University, Addis Ababa, Ethiopia.

Pharo, H. and S.P. Cobb, 2011. The spread of pathogens through trade in pig meat: Overview and recent developments. Rev. Sci. Tech. Off. Int. Epiz., 30: 139-148.

Reid, S.M. N.P. Ferris, G.H. Hutchings, A.R. Samuel and N.J. Knowles, 2000. Primary diagnosis of foot-andmouth disease by reverse transcription polymerase chain reaction. J. Virol. Methods, 89: 167-176.

Roeder, P.L., G. Abraham, G.Y. Mebratu and R.P. Kitching, 1994. Foot-and-mouth disease in Ethiopia from 1988 to 1991. Trop. Anim. Health Prod., 26: 163-167.

Rufael, T., A. Catley, A. Bogale, M. Sahle and Y. Shiferaw, 2008. Foot and mouth disease in the Borana pastoral system, southern Ethiopia and implications for livelihoods and international trade. Trop. Anim. Health Prod., 40: 29-38.

Rushton, J., 2009. The Economics of Animal Health and Production. CABI, Wallingford, UK., ISBN: 978-184593-194-0, Pages: 364.
Rweyemamu, M., P. Roeder, D. Mackay, K. Sumption and J. Brownlie et al., 2008. Epidemiological patterns of foot and mouth disease worldwide. Transbound. Emerging Dis., 55: 57-72.

Samuel, A.R. and N.J. Knowles, 2001. Foot-and-mouth disease type $O$ viruses exhibit genetically and geographically distinct evolutionary lineages (topotypes). J. Gene. Virol., 82: 609-621.

Savill, N.J., D.J. Shaw, R. Deardon, M.J. Tildesley and M.J. Keeling et al., 2006. Topographic determinants of foot and mouth disease transmission in the UK 2001 epidemic. BMC. Vet. Res., Vol. 2, 10.1186/1746-6148-2-3

Shaw, A.E., S.M. Reid, K. Ebert, G.H. Hutchings, N.P. Ferris and D.P. King, 2007. Implementation of a one-step real-time RT-PCR protocol for diagnosis of foot-and-mouth disease. J. Virol. Methods, 143: 8185.

Sissay, M., D. Delesa and M.D. Getachew, 2017. Serotyping and molecular characterization of foot and mouth disease of cattle in central Ethiopia. M.Sc. Thesis, Harmaya University, Ethiopia.

Sulayeman, M., F. Dawo, B. Mammo, D. Gizaw and D. Shegu, 2018. Isolation, molecular characterization and sero-prevalence study of footand-mouth disease virus circulating in central Ethiopia. BMC. Vet. Res., Vol. 14, 10.1186/s12917018-1429-9

Sumption, K., J. Pinto, J. Lubroth, S. Morzaria, T. Murray, S.D.L. Rocque and F. Njeumi, 2007. Footand-Mouth disease situation worldwide and major epidemiological events in 2005-2006. Food and Agriculture Organization, Rome, Italy. http://www.fao.org/3/a-ai339e.pdf

Sutmoller, P., S.S. Barteling, R.C. Olascoaga and K.J. Sumption, 2003. Control and eradication of foot-andmouth disease. Virus Res., 91: 101-144.

Tadesse, B., W. Molla, A. Mengsitu and W.T. Jemberu, 2019. Transmission dynamics of foot and mouth disease in selected outbreak areas of northwest Ethiopia. Epidemiol. Infect., Vol. 147. 10.1017/S0950268819000803

Tefera, 2010. Sero-prevalence, involvement of small ruminants in the epidemiology of FMD and characterization of FMD virus circulating in the study area and assess epidemiological risk factors associated with FMD in cattle in selected districts of Gambella region, Ethiopia. M.Sc. Thesis, Addis Ababa University, Addis Ababa, Ethiopia.

Tesfaye, Y., 2014. Isolation, molecular characterization and vaccine matching of foot and mouth disease virus circulating in Ethiopia. M.Sc. Thesis, Addis Ababa University, Addis Ababa, Ethiopia. 
Thomson, G.R., W. Vosloo and A.D.S. Bastos, 2003. Foot and mouth disease in wildlife. Virus Res., 91: 145-161.

Tikuye, S., 2019. Antigen detection and molecular characterization of foot and mouth disease virus from outbreak cases in Ethiopia. M.Sc. Thesis, College of Veterinary Medicine and Agriculture, Addis Ababa University, Bishoftu, Ethiopia.

Urge, B. and D. Gizaw, 2018. Serotype identification, molecular based detection and characterization of FMD virus isolated from outbreak cases in selected areas of Oromia Region, Ethiopia. Glob. J. Sci. Front. Res. Agri. Vet., 18: 33-57.

Urge, B., 2017. Serotyping and molecular characterization of FMD virus isolated from outbreak cases in selected region and Addis Ababa, Ethiopia. M.Sc. Thesis, College of Veterinary Medicine and Agriculture, Addis Ababa University, Bishoftu, Ethiopia.

Urge, B., F. Dawo, D. Gizaw, M. Sombo and A. Muluneh et al., 2019. Farm based outbreak study and Genetic characterization of $\mathrm{O}$ serotype foot and mouth diseases virus isolated from clinical cases in dairy farms of Welmera district, Central Oromia, Ethiopia. Green. J. Agri. Sci., 9: 302-308.
Vosloo, W., A.D. Bastos, O. Sangare, S.K. Hargreaves and G.R. Thomson, 2002. Review of the status and control of foot and mouth disease in sub-Saharan Africa. Rev. Sci. Tech., 21: 437-449.

Wagari, A., 2016. Seroprevalence of foot and mouth disease in bulls of Borana origin quarantined in Adama. Int. J. Biochem. Biophys. Mol. Biol., 1: 110.

Wondwossen, T., 2017. Isolation, molecular characterization and vaccine matching of foot and mouth disease virus circulating in central Ethiopia. M.Sc. Thesis, College of Veterinary Medicine and Agriculture, Addis Ababa University, Bishoftu, Ethiopia.

World Organization of Animal Health (OIE), 2012. Manual of Diagnostic Tests and Vaccines for Terrestrial Animals (Mammals, Birds and Bees). 7th Edn., Vol. 2. World Organization of Animal Health (OIE), France.

Xu, L., W. Hurtle, J.M. Rowland, K.A. Casteran and S.M. Bucko et al., 2013. Development of a universal RTPCR for amplifying and sequencing the leader and Capsid-coding region of Foot-and-mouth disease virus. J. Virol. Methods, 189: 70-76.

Yirgalem, M., 2018. Molecular characterization of foot and mouth disease viruses in cattle from outbreaks occurred in different parts of Ethiopia from October, 2017 to May, 2018. M.Sc. Thesis, College of Veterinary Medicine and Agriculture, Addis Ababa University, Bishoftu, Ethiopia. 